Article

\title{
Climate Change-Induced Migration in Coastal Bangladesh? A Critical Assessment of Migration Drivers in Rural Households under Economic and Environmental Stress
}

\author{
Amelie Bernzen ${ }^{1}{ }^{\complement}$, J. Craig Jenkins ${ }^{2}$ and Boris Braun ${ }^{1, *}$ \\ 1 Institute of Geography, University of Cologne, 50923 Cologne, Germany; a.bernzen@uni-koeln.de \\ 2 Mershon Center for International Security Studies, The Ohio State University, Columbus, OH 43201, USA; \\ jenkins.12@osu.edu \\ * Correspondence: boris.braun@uni-koeln.de
}

Received: 21 December 2018; Accepted: 15 January 2019; Published: 18 January 2019

\begin{abstract}
Discussions of climate migration have recognized the need for probabilistic, systematic, and empirical analyses. We examine the importance of environmental stressors in migration using a multi-leveled analysis of a household survey of the climate-stressed rural communities of coastal Bangladesh. We find that a relatively small share (6.5\%) of rural coastal people have migrated, overwhelmingly domestically and on a temporary basis. The main motives are better employment opportunities in urban areas, marriage/family reunification, and education. About a third are displaced by flooding that created loss of arable land. Being male, younger, and working outside of agriculture facilitate migration, and also those with greater human and horizontal social capital are more likely to migrate. Exposure to severe river erosion, residing closer to major waterways and in saltwater shrimp farming zones spur migration. Climate migration is in its first instance economic-induced with environmental stress contributing as a secondary factor.
\end{abstract}

Keywords: climate migration; migration motives; cyclones; erosion; environmental stressors; coastal Bangladesh; rural households

\section{Introduction}

Discussions of "climate migration" have increasingly recognized the need for studies of actual behavior and a more complex probabilistic approach in which climate stressors are analyzed alongside other socioeconomic and political drivers (e.g., [1,2]). Early contributions to the climate migration problem (e.g., [3-6]) simply estimated the population at risk of major climate hazards, assuming that all will be displaced and neglecting to analyze the complex dynamics involved in actual migration behavior. While this can be useful to raise academic and public awareness, it greatly oversimplifies the migration process. Several authors have criticized the vagueness of what constitutes a "climate migrant" and the various attempts at numerical estimates of future climate migration [7-10]. Others have pointed to the complexity of how environmental stressors actually affect migration, typically working indirectly by affecting other social, economic, political, and demographic drivers of migration [11-15]. As summarized by Findlay [16] (p. 57), "the most likely effect of environmental change over the next 50 years will be to amplify and modify pre-existing migration channels".

This paper examines the migration behavior of rural residents in coastal Bangladesh, which is one of the most climate-stressed areas of the world [17-20]. With a population of nearly 60 million, over a third of whom are poor according to international standards, these coastal communities confront both sudden onset climate hazards such as extreme flooding, storm surges, and river bank 
erosion as well as slow onset challenges of growing salinization, land subsidence, and sea-level rise [21-23]. While total sediment load from the Ganges-Brahmaputra-Meghna river system appears to be maintaining a relatively stable delta [24], the polder or flood wall system diverts this sedimentation outside of the protective walls and contributes to land subsidence and waterlogging inside polder walls [25,26]. Many of these environmental hazards threaten rural households, creating a potential "push" to migrate. Other human interventions, such as the diversion of the Ganges River at the Farakka Barrage and the conversion of rice paddies into saltwater shrimp farming, are contributing to salinization and greater environmental stress, seen by many as drivers of rural out-migration $[25,27,28]$.

However, migration is also a response to economic opportunities and the major social and economic disparities between rural and urban areas. Most migrants are seeking economic oppor-tunities, especially better jobs that will allow them to make a living and perhaps send remittances back to their families in the countryside [29]. Most of this migration is temporary with many returning home within less than six months. Of permanent migration in coastal Bangladesh, over two-thirds is rural-to-urban, which has grown enormously in the past three decades [30,31]. In 1984, the permanent rural-urban migration rate per decade was 1.2 per thousand, but by 2010 has exploded to 22.5 [30,32]. This has created burgeoning urban slums, where 40 to 50 percent of all residents are rural immigrants [33]. Some contend that it is the poor who are typically the most vulnerable to flooding and who are forced to move as a "last resort" [34-36], while others emphasize that moving requires resources and the more resourceful are more likely to move [32-39]. Still others point to the importance of commitment to place, which discourages migration [15].

Many existing migration studies are poorly designed for addressing the multiple drivers behind migration. Several studies examine only displaced natural disaster victims [36] or communities that are highly exposed to major climate hazards, such as cyclones and severe river erosion [35,40-42]. Others look only at migrants who have resettled in the urban slums [33,43]. While these studies document the major human challenges faced by disaster migrants, from the viewpoint of studying the causes of migration, they select on the dependent variable. Comparison with non-migrants is needed. A second problem is that many of these studies do not control for the broader set of both "push" and "pull" and enabling factors that may influence migration behavior. To overcome these limitations, we use a survey of a locally representative sample of rural households from nine union parishads in coastal Bangladesh, allowing us to compare migrants with non-migrants. Our paper specifically asks: What is the importance of environmental stressors relative to other socioeconomic, demographic, and political factors (i.e., both "push" and "pull") for out-migration? Is it the poor or the resourceful who migrate? Do the effects vary among different types of migrants (temporary/permanent, domestic/international)?

\section{Climate Change, Environmental Hazards, and Migration}

Recent research shows signs of climate change in Bangladesh, but the details are complex and exhibit significant gaps in our knowledge. Five climate change indicators have received extensive attention in Bangladesh: annual mean temperatures, precipitation, extreme flooding events, cyclone frequency and intensity, and salinization of rivers, groundwater, and soils.

Islam and Neelim [44] find an increase in annual mean temperatures between 1948 and 2007, but no clear trend in rainfall totals or extremes. Cases of extreme flooding tended to increase between the 1950s and the early 2000s, but more recent flooding data from the Bangladesh Water Development Board does not support the assumption of an increase of extreme flood events over time [45] (p. 340-342), [46] (p. 7). The frequency and intensity of cyclones experienced a long-term increase dating back to the 19th century. The post-2000 period, however, has shown declining frequency and intensity, suggesting no clear trend in cyclone formation over the Bay of Bengal [17] (p. 141-143), [47]. However, the development of the coastal region has put greater assets at risk, meaning that property damage from storms has significantly risen since the 1970s, but improved 
disaster preparedness and response has reduced human casualties, injury, and disease [48]. In recent years, cyclones Sidr (November 2007) and Aila (May 2009) created major damage in our study sites.

Another environmental challenge is salinization, which is growing in terms of the rivers, groundwater, and soil affected. Sea-level rise, including land subsidence, plays a role, but is further aggravated by human interventions, such as the diversion of the Ganges at the Farakka Barrage in India, which has reduced the flow of freshwater into the southwest region of Bangladesh [27], and by increased water pumping for irrigation, industry, and household use [49,50]. Simulation models project that over the next 50 to 100 years, climate change and other human interventions may increase the share of moderate to highly saline river area in the southwest further by as much as 40 percent and create even greater shortages of drinking and useable irrigation water [50].

How do these dynamics affect migration behavior? As Fussell et al. [1] argue in their literature review, environment-migration research needs to integrate multiple environmental stressors along with other determinants of migration and recognize that there are costs and migration obstacles that "trap" populations. Environmental stressors can be both reasons for and obstacles to migration [51]. Some studies have looked at the rural immigrants who have settled in the urban slums, i.e., receiving community studies. Istahique and Ullah [33] find that both "push" (i.e., economic hardship, family problems, natural disasters, threats of violence) and "pull" factors (e.g., perceived economic opportunities, positive views of city living) influenced the decisions to migrate and that about 10 percent of these migrations were due to natural disasters, typically leading to destruction of farmland and housing by severe river erosion or cyclones. These disaster migrants represent only a small share of all rural-urban migrants, but they are an extremely vulnerable segment, reporting major disruptions in their household income and loss of their household assets. They also find support for the "environmental capital" thesis [2] that farm households with greater land access are more likely to have one or more members migrate.

Overall, a stronger approach is to sample the rural sending communities. Although this underestimates permanent migration because entire households may have already moved and not be included in the sending community survey, this provides a more representative basis for comparing migrants vs. non-migrants than receiving community surveys. Several studies have focused on rural sending communities that were strongly affected by cyclone damage and other environmental hazards, finding that poor households were the most likely to migrate in response to storm damage. Interviewing households in villages that were selected because of greater damage from Cyclone Aila in 2009, Mallick and Vogt [35,42] found that 35 percent of all rural households had one or more migrants. The poor and landless, especially day laborers, were the most likely to migrate, typically younger males seeking income to send back to their families. Other researchers have highlighted the importance of land use changes associated with shrimp farming. Azam's [52] small-scale $(\mathrm{N}=5)$ qualitative interviews in two rural upazilas south of Khulna show that the introduction of shrimp farming has little benefits to the poor, reduces local employment opportunities, destroys neighboring farmland due to salt leaching, and undermines physical resilience against storms and flooding [53]. Many resorted to temporary migration to both major cities and rural areas for agricultural, construction, and urban service jobs. Azam and Falk [54] (p. 7) contend that "climate change is not a driver of migration", but rather this type of economically induced land use change. In a study of two rural sending communities in northern Bangladesh, Ullah [27] found that about 5 percent migrated because of crop loss and damage linked to flooding and drought. Overall, environmental hazards were secondary to a wide variety of other economic and social factors.

Most damaging to the "climate migrant" thesis are two studies with broader sending community coverage. Drawing on a longitudinal survey of 102 rural communities distributed across multiple regions of Bangladesh, Gray and Mueller [55] conclude that "flooding undoubtedly causes substantial short-term population displacement but it appears that this translates into few long-term moves". A similarly skeptical conclusion comes from Chen et al. [56] and Chen and Mueller [57]. Using annualized Vital Statistics (2003-2011) measures and MODIS satellite images, they find 
that flooding has a negative effect on permanent migration. Either households are trapped by flooding or flooding is boosting local crop yields which create local employment, which discourages migration.

An important question is whether it is the poor or the rich who migrate. As we have seen, there are conflicting arguments about whether the poor are more exposed to hazards and thereby more likely to be displaced or those with more individual resources (e.g., education, English skills, income, owning farmland or a business, positive ethnic status, and social capital) are more likely to move. Some assets are mobile, such as human capital (education, English skills) and might therefore encourage mobility. Others, such as owning a farm, strong network access to local elites or dominant ethnic status, might anchor one in a specific community. Having non-agricultural jobs might enable migration by making for more transferable skills and weaker ties to the local rural community [33]. Several studies show that men are more likely to move, responding to gender roles as breadwinners by moving to gain cash income, leaving women, children, and the elderly in the rural village, and sending back remittances. Mallick and Vogt [35] find that higher income encourages migration, but owning farmland and local elite ties discourage it. Although they do not control for climate hazards, Akhter and Bauer [58] find that households with larger farms are less likely to migrate. Gray and Mueller [55] and Chen et al. [56] both find that the poor are less likely to migrate due to scarce resources despite being more vulnerable to environmental hazards.

This past research identifies an underlying debate about the significance of environmental stressors associated with climate change and the importance of demographic and other resources that influence migration. Some have emphasized the importance of environmental stressors that "push" people into migration, including the possibility that these may work indirectly or in conjunction with other factors as well as directly. Others have emphasized the resources and opportunities that lead to migration, including the constraints and resources of current occupations, gender and family roles, human capital, and the like. These views might seem conflicting, but there may be multiple driving forces and migration streams at work. So, for example, it is possible that environmental stressors differentially affect the poor while the better resourced are overall more likely to migrate. Figure 1 provides an overview summary of the corresponding hypotheses, indicating the likely direction of different independent variables to produce migration.

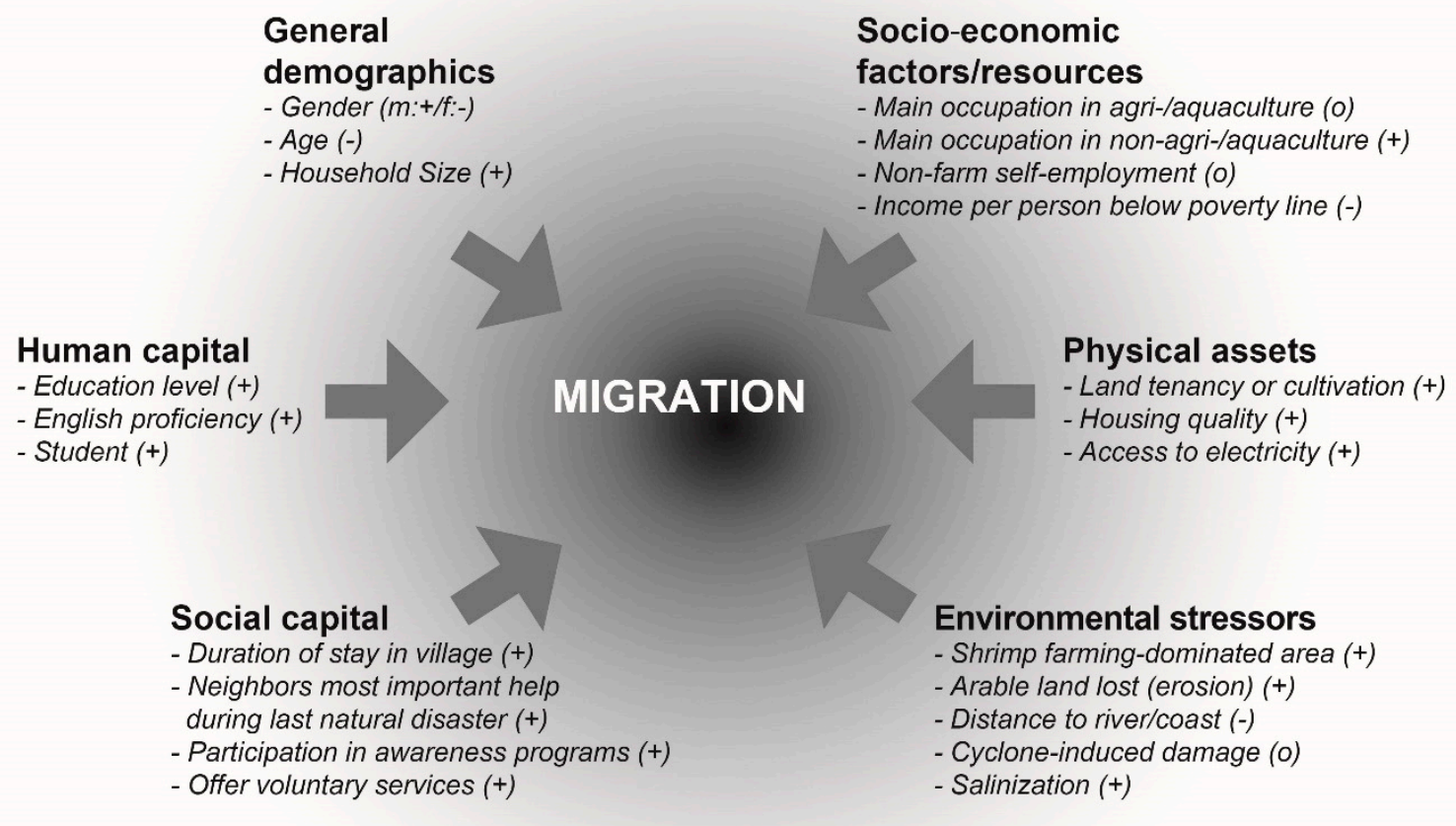

Figure 1. Predicted effects of selected independent variables on migration. 


\section{Methodology}

\subsection{Household Survey}

To develop more representative data about rural migration, we conducted standardized household interviews in nine union parishads in five districts of coastal Bangladesh between October and December 2014. Coastal Bangladesh was chosen because it is the most vulnerable area of Bangladesh in terms of exposure to cyclones, storm surges, river bank erosion, soil salinization, and other climate-change-driven environmental hazards. This survey was part of the international Belmont Forum BanD-AiD project that assembled an interdisciplinary team to assess sea-level rise and climate change and the adaptation of the rural population to these challenges. A union parishad, which often contains multiple settlements or mouzas, is the smallest governmental administrative unit in Bangladesh, superseded by upazilas (sub-districts), zilas (districts), and bibhag (divisions). Unions are more stable as entities because of their local government functions, making them a more viable unit of data collection than mouzas, for which there is very limited census and other data.

All of our study sites were selected during a first field visit early in 2014. They represent rural communities on poldered land in different areas of the Ganges-Meghna-Brahmaputra delta which features unique morphological dynamics that cannot be found along the eastern Chittagong coast of Bangladesh. The communities were further selected to represent a broad variety of geographic, socio-economic coastal, and environmental circumstances: different bio-ecological zones, different levels of transport accessibility, different land uses and exposure to natural hazards such as floods, severe river erosion, storm surges and cyclones, and different demographic trends (i.e., negative vs. positive population change between the 2001 and 2011 censuses). Finally, pragmatic and logistical reasons contributed to the selection of the unions. They needed to be accessible by road and, in some cases, we had established contact to local council representatives or other organizations. Table A1 lists the 9 unions where interviews were conducted and the types of areas they represent and Figure 2 shows their location.

The target sample size for interviews in each study site was 150 households (representing between 1.7 and 2.8 percent of the union's population, respectively) with the final sample being 1188 households (covering data on 6132 individuals). The aim was to collect data on the union level and only one union per study site in order to better compare collected data to statistics published by the Bangladesh Bureau of Statistics (BBS). In one case, though, borders between unions were crossed (Koyra; Amadi and Bagali unions, where a major river divides the settled area). To cover different parts of the union area, field assistants—students and graduates of Rajshahi University, a partner university within the BanD-AiD project-were asked to identify all mouzas across the union, allocate a relatively similar target subsample (quota of the 150) to each and approach households by moving from the center of the settlement (e.g., market square) towards the outer edges of the settlement along a major road/track and —-depending on the size of the mouza-contacting every third to fifth household (or the next household if no one was available at the targeted household).

Each interview took approximately 60 to 90 minutes and consisted of 55 questions which included fixed choice and open-ended items. The questionnaire covered six sections with the following themes: (1) information on location and type of house, (2) socio-demographic characteristics of the household members (including migration experience), (3) land access and land use, (4) food security, consumption, and livelihood adaptation, (5) social interaction and participation, (6) experience with livelihood problems and natural disasters. We also asked about the main reason for migration, including reported experience with cyclones, floods, and erosion. Field assistants were trained by the authors prior to and during data collection and conducted face-to-face interviews in Bangla, asking the questions and writing the respondent's self-reported answers on the survey sheet. A few variables like the GIS location used to calculate "distance to next river/coastline" or "housing condition" were observed and recorded by the interviewer. Both male and female field assistants were employed as it was assumed that, due to cultural etiquette, female interviewers would have better access to 
female respondents of households. Interviews were held in most cases with the household head (85.3 percent of respondents: 973 male, 40 female) or his/her spouse (11.6 percent of respondents: 2 male, 136 female). After the data collection, field assistants entered the data into an online survey mask which exported the data directly into SPSS software.

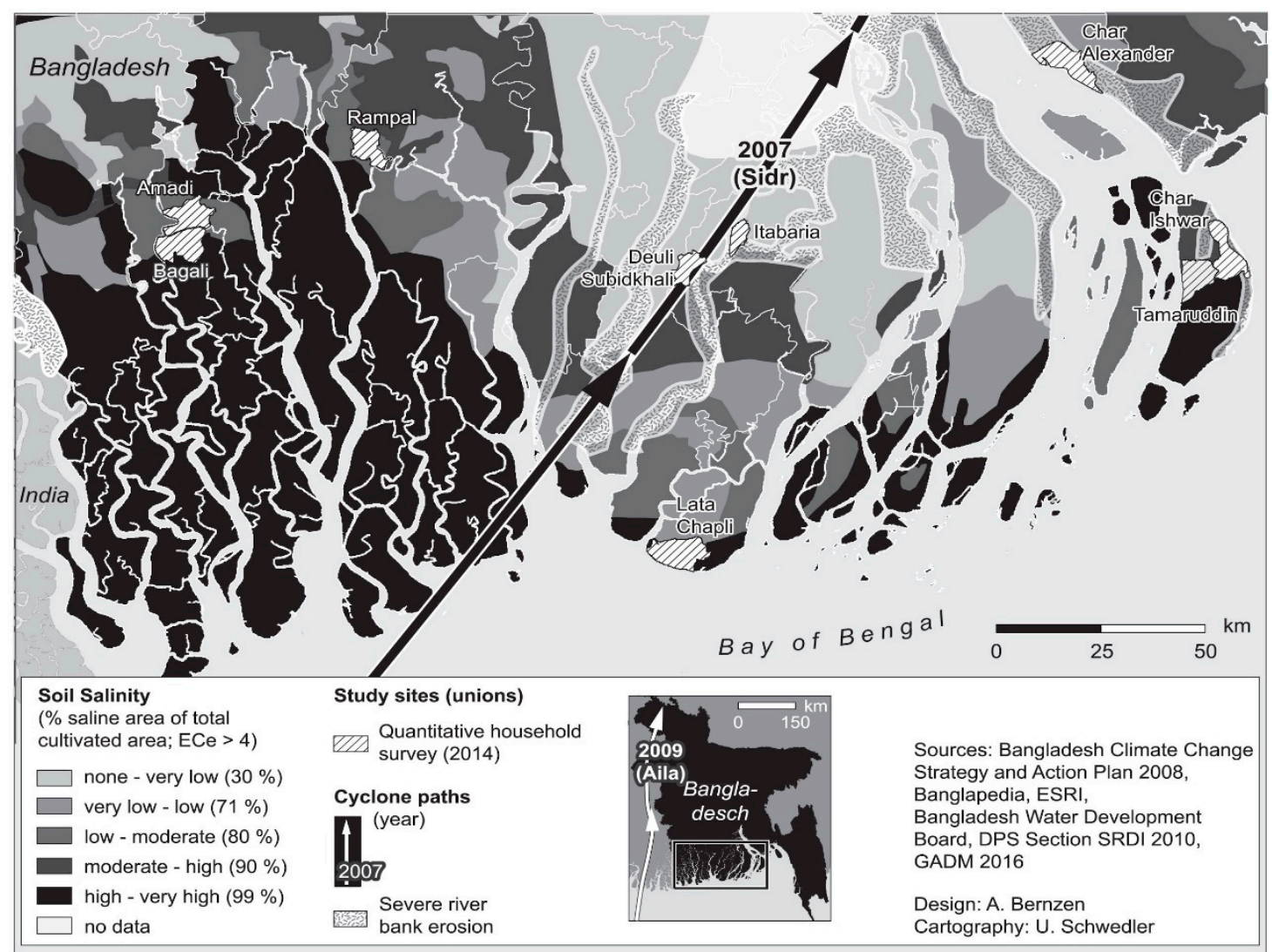

Figure 2. Soil salinity, Sidr and Aila cyclone paths, riverbank erosion risk areas, and study sites.

\subsection{Dependent and Independent Variables: Measures and Analysis}

The dependent variable (migration) was collected on an individual level as were important socio-demographic characteristics such as gender, age, education, English skills, and employment status, including major occupation, full-time student status, etc. Migration as the dependent variable (yes $=1$; no $=0$ ) was operationalized as any move from the household in which the person no longer ate meals at the household table, including moves both within the same union and outside the union. We used a lifetime memory approach, asking our household respondents to report any household member that had migrated, indicating whether each individual's move had been of temporary or permanent nature (temporary $<=6$ months of absence; permanent $>6$ months of absence), and occurred domestically or internationally. While near-term events may be generally easier to remember than those long ago, it does not seem likely that respondents would have trouble recalling such significant household changes, and our field assistants reported no confusion or uncertainty with this question. Finally, we control in our models below for respondents' age and the duration of household residence in the community, which should help correct for errors in this lifetime recall.

Our independent variables (IVs) were selected on the basis of the above discussion of past research (Figure 1). They include indicators for (1) individual and household demographics, (2) human capital, (3) social capital, (4) other socio-economic resources, (5) physical assets, and (6) environmental stressors. More specifically, the latter include five indicators covering three of the most frequently addressed environmental stressors in the literature (Section 2 above, [31]): First, two controls for the household's "exposure" i.e., natural hazard likelihood: (1) Saltwater shrimp farming upazila (indicator for 
above-average soil and water salinity) and (2) Distance of household to the next major river or coastline (indicator for exposure to flooding hazards; calculated from GPS location information). Second, we included direct event reports from the survey which control for severe flooding, cyclone activity and salinization: (3) Reported arable land loss (indicator for erosion); (4) Reported household expenditures related to cyclone damage and (5) Reported problems with freshwater availability due to salinization. These indicators allow us to identify whether individuals living in households that are exposed to or affected by any of these hazards are more likely to migrate.

Measures for each indicator were constructed from the questionnaire items and are presented in Table 1 (here sorted into individual and household level characteristics).

Table 1. Independent variables-Individual and contextual household characteristics.

\begin{tabular}{|c|c|c|c|c|c|c|}
\hline Label & Data Source & Mean & Std.Dev. & Min & Max & Obs. \\
\hline \multicolumn{7}{|l|}{ Individual Characteristics } \\
\hline Gender (male $=1$, female $=2$ ) & self-reported & 1.46 & 0.49 & 1 & 2 & 4456 \\
\hline Age (years) & self-reported & 36.25 & 16.71 & 15 & 120 & 4456 \\
\hline Education $($ secondary or higher $=1$ ) & self-reported & 0.24 & 0.43 & 0 & 1 & 4451 \\
\hline $\begin{array}{l}\text { Basic English language proficiency or } \\
\text { higher (yes = 1) }\end{array}$ & self-reported & 0.21 & 0.41 & 0 & 1 & 4456 \\
\hline Student $($ yes $=1)$ & self-reported & 0.13 & 0.34 & 0 & 1 & 4456 \\
\hline $\begin{array}{l}\text { Main occupation in agri-/aquaculture } \\
(\text { yes =1) }\end{array}$ & self-reported & 0.28 & 0.45 & 0 & 1 & 4456 \\
\hline $\begin{array}{l}\text { Main occupation in non-agri-/aquaculture } \\
\text { (yes =1) }\end{array}$ & self-reported & 0.21 & 0.41 & 0 & 1 & 4456 \\
\hline Non-farm self-employment (yes $=1$ ) & self-reported & 0.16 & 0.36 & 0 & 1 & 4456 \\
\hline \multicolumn{7}{|l|}{ Household Characteristics } \\
\hline $\begin{array}{l}\text { Household size (number of persons } \\
\text { in household) }\end{array}$ & self-reported & 5.67 & 1.88 & 1 & 12 & 4456 \\
\hline $\begin{array}{l}\text { Income per person below poverty line } \\
(\text { yes }=1)\end{array}$ & self-reported & 0.85 & 0.36 & 0 & 1 & 4456 \\
\hline Shrimp farming dominated area $($ yes $=1$ ) & self-reported & 0.27 & 0.44 & 0 & 1 & 4456 \\
\hline $\begin{array}{l}\text { Arable land lost (mainly due to erosion) } \\
\text { (yes =1) }\end{array}$ & self-reported & 0.19 & 0.39 & 0 & 1 & 4456 \\
\hline $\begin{array}{l}\text { Distance to next major river or coast } \\
\text { (meters) }\end{array}$ & $\begin{array}{l}\text { measured } \\
\text { via GPS data }\end{array}$ & 1236.30 & 1167.07 & 11 & 4540 & 4412 \\
\hline Cyclone-induced damage (yes $=1$ ) & self-reported & 0.54 & 0.49 & 0 & 1 & 4456 \\
\hline Salinization $($ yes $=1)$ & self-reported & 0.23 & 0.42 & 0 & 1 & 4456 \\
\hline Land tenancy or cultivation (yes $=1$ ) & self-reported & 0.73 & 0.44 & 0 & 1 & 4456 \\
\hline $\begin{array}{l}\text { Housing condition }(\text { Pacca }=1 \text {, } \\
\text { Semi-Pacca }=2, \text { Kaccha }=3)\end{array}$ & $\begin{array}{l}\text { assessed by } \\
\text { interviewers }\end{array}$ & 2.52 & 0.66 & 1 & 3 & 4418 \\
\hline Access to electricity (yes $=1$ ) & self-reported & 0.28 & 0.45 & 0 & 1 & 4390 \\
\hline Period of residence in community (years) & self-reported & 43.61 & 18.37 & 0 & 100 & 4438 \\
\hline $\begin{array}{l}\text { Neighbors most important help during } \\
\text { last natural disaster (yes }=1 \text { ) }\end{array}$ & self-reported & 0.25 & 0.43 & 0 & 1 & 4456 \\
\hline $\begin{array}{l}\text { Participation in community } \\
\text { awareness-raising programs (yes }=1 \text { ) }\end{array}$ & self-reported & 0.35 & 0.47 & 0 & 1 & 4456 \\
\hline $\begin{array}{l}\text { Household offers voluntary services } \\
\text { in local community (yes }=1 \text { ) }\end{array}$ & self-reported & 0.01 & 0.10 & 0 & 1 & 4456 \\
\hline
\end{tabular}




\subsection{Statistical Model}

Because individuals are ultimately the actors that actually do the migration, and our interest includes whether individual level traits, such as human and social capital, influence migration behavior, it is conceptually useful to analyze migration behavior as an individual-level outcome that may be shaped by both individual and household level characteristics. We therefore use a multi-leveled model in which individuals are treated as nested within households. We have individual-level data on 6132 individuals who are nested within 1188 households. Of these 6132 individuals, we look only at those 15 years of age and older (i.e., adults), creating a maximum $\mathrm{N}$ of 4456 . We use the mixed-effects logistic regression model (melogit) in Stata 15 for our main results, clustering errors by household. This approach corrects for potential bias created by the household interviewing method as well as the non-independence of the individuals within each household.

\subsection{Limitations}

The advantage of studying sending communities is that it allows us to compare those who migrate with those who do not, something studies who limit themselves to receiving communities cannot accomplish. Yet, it is important to note limitations of our approach. First, it is likely to underestimate migration because of possible problems of recall for early moves and the permanent out-migration of entire households who cannot be captured by our survey. Second, our data does not allow us to disentangle the relationship between the timing of the migration event and exposure of households to environmental hazards. We are, however, able to control for the period of exposure (IV: period of residence in the community) and variables which indicate whether households have (ever) been affected by different natural hazards or are currently exposed to environmental hazards. Another limitation is that for logistic reasons in particular, not all mouzas could be covered in all unions. Because the study is limited to selected sites, we cannot control for the full range of potential environmental risks throughout the coastal zone, but our measures do capture the major climate stressors discussed in the literature on coastal Bangladesh [31]. Finally, this sampling strategy does not claim to generate nationally representative results. The unions are merely illustrative of the rural coastal zone, covering both families whose income is based primarily on agricultural and non-agricultural income sources, respectively.

\section{Results and Discussion}

\subsection{Descriptives of Migrants, Migration Types, and Motives}

Of our sample of 4456 adults, 279 migrated, which represents a migration rate of $6.3 \%$. The share of migrants in our sample is similar to that found by Gray and Mueller [55], which cover 15 years compared to our lifetime memory measure, and by Chen et al. [56] who used Vital Statistics between district permanent migration measures. 196 of our 1188 households experienced cases of migration by one or more household members, i.e., $16.5 \%$ of all households, with the overwhelming majority reporting one person as a migrant (11\% of all households), $3 \%$ reporting two migrants and $2 \%$ three or more. Migration may be temporary (up to 6 months; $88 \%$ of all migrants) or permanent (more than 6 months; $12 \%$ ) and may be internal (88 \%) or international (12\%, Figure 3 ).

So why do rural people migrate? In a descriptive approach, we asked respondents for the main reason for their migration (Figure 3). Overall, of the roughly $60 \%$ of individuals for whom we have a main rationale $(\mathrm{n}=167), 57 \%$ moved because of better employment opportunities in the city, $20 \%$ due to marriage and family reunion, and $17 \%$ for studying or educational opportunities. Economic or social opportunities were cited as the most important reason for migrating overall. Environmental hazards were not mentioned, even though we used a list of closed-ended questions ("What is the main reason for migrating?" 1 = better opportunities to work in city (rural to urban migration), $2=$ better opportunities to work in agriculture, $3=$ studying/education, $4=$ marriage, $5=$ other family reunification, $6=$ infertile soils $7=$ cyclone $/$ storm surge, $8=$ flood, $9=$ erosion, $10=$ political unrest, $11=$ conflict 
with landlord/musclemen, 12 = other). International migration is motivated only by off-farm work opportunities, education and, in two cases, for marriage/family reunification. Marriage-in most cases women moving to their husband's households-accounts for almost the same share of permanent domestic moves (41\%) as job opportunities in urban areas (45\%). Domestic temporary migration is likewise driven above all by urban job opportunities (59\%), followed by education (21\%).

Our statistical analysis first tests bivariate relationships and appropriate bivariate tests (chi ${ }^{2}, \mathrm{t}$-test) between the IVs and the DV. Second, as our dependent variable is dichotomous (migrant yes/no) and individuals are nested within households (which are nested within unions), we used a multi-level mixed-effects (also known as hierarchical) logistic regression modeling approach with all selected IVs based on their theoretical or statistical significance in the bivariate tests (Table 2).

\section{A. Main reasons for migration}

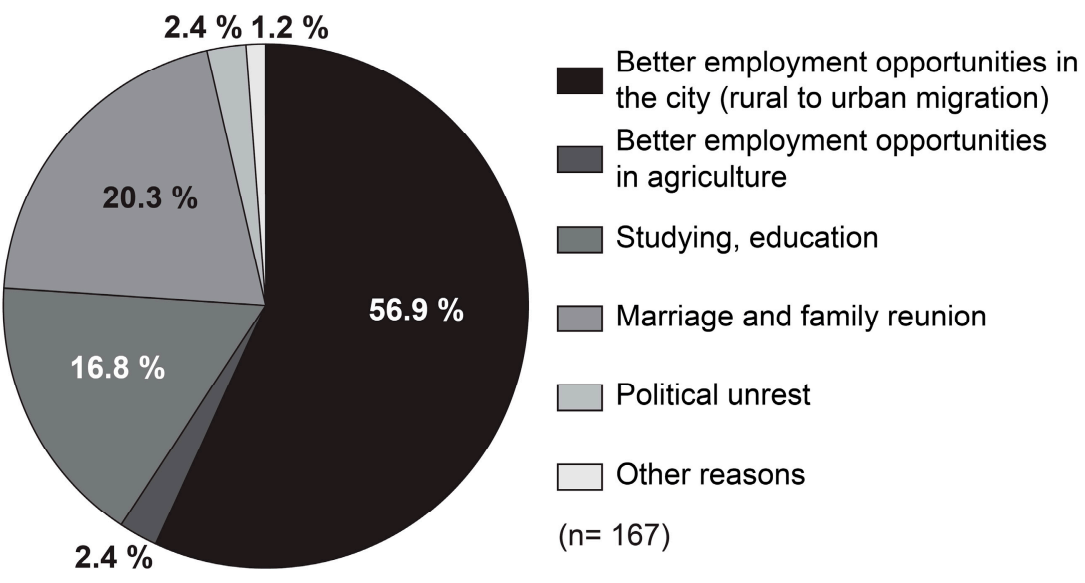

B. Type and destination of migration

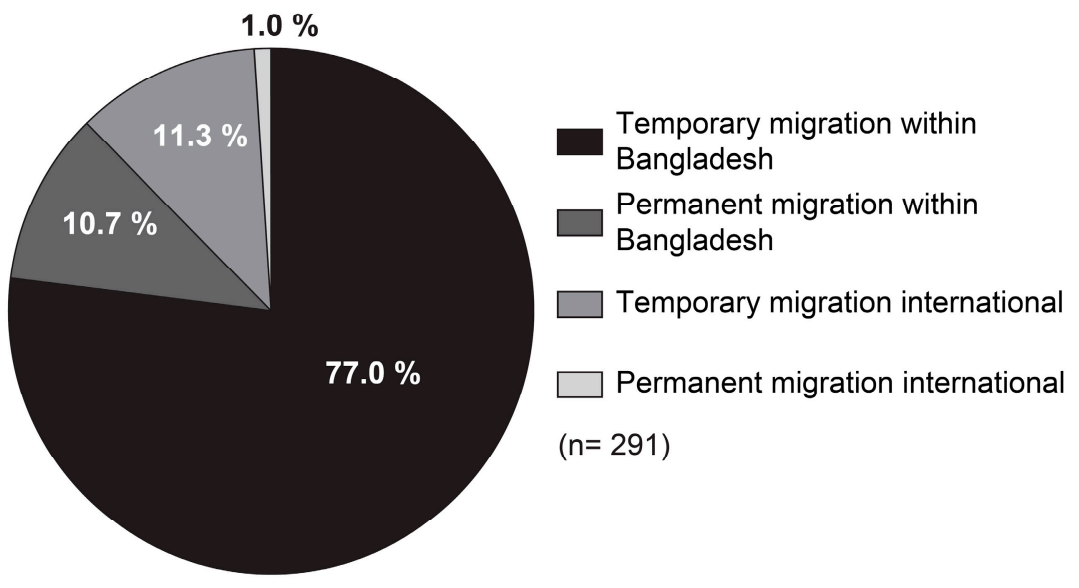

Figure 3. Main reasons for migration (A) and types/destinations of migration (B).

\subsection{Bivariate Results}

Table 2 presents the bivariate test results for all migrants age 15 and over. In terms of general demographics, men are significantly more likely to migrate than women. A total of 227 (9.4\%) men migrated, while only 52 (2.5\%) women migrated, 19 of the latter for marriage reasons. Of all women for whom we have a rationale for migrating, marriage constitutes $47.5 \%$. By contrast, men migrated largely for economic opportunities: 86 (69.9\%) migrated for better job opportunities in urban areas. Also, younger individuals migrate more often. We found a significant average age difference between migrants (28 yrs.) and non-migrants (37 yrs.). Household size has a negligible 
impact on migration, but we did find that households with more adult males were more likely to have out-migrants.

Looking at human capital characteristics, those with more education (secondary school or higher) and English speakers are more likely to migrate. The group of students also shows a higher share of migrants. All of these indicators suggest people with cognitive resources, basic skills, and willingness to take risks.

Looking at the next set of IVs, socio-economic factors, and resources, our data shows that households which have an average monthly income at or above the poverty line of USD 1.90 per day/person are more likely to migrate, albeit this is a relatively modest positive relationship. In other words, we may assume that individuals from more affluent households are more likely to migrate. At the household level, there is also a modest positive relationship between having individuals with a college/university degree and household income (Spearman rho $=0.244, p=0.000$ ), which becomes relevant later in terms of deciding whether income or education is more important for migration decisions. For now, the main point is that migration appears to be positively associated with greater resources. Looking at occupation, those who identify agriculture or aquaculture as their primary occupation in terms of earnings are much less likely to migrate than those who are engaged primarily in non-agricultural/aquacultural jobs. At the same time, individuals who are self-employed in the non-agriculture/aquaculture sector are less likely to migrate than all others. Both agri-/aquaculture and local non-agricultural self-employment imply more investment in the rural community which is primarily organized around managing land and local infrastructure which seems to result in a reluctance to migrate. We will later examine this in terms of its relationship net of other predictors.

Looking next at environmental stressors, our overall results suggest that between 2 and 4 percent of all adult individuals in our sample are migrants who have experienced significant flooding in the immediate vicinity of their houses. Of our total sample, 74 are migrants who had permanently lost arable land due to flooding or river erosion, and 163 are migrants who had experienced damage from cyclones. The overwhelming majority migrated temporarily, and they were not disproportionately poor relative to the overall sample given their type of housing (kaccha or mud/bamboo huts) or their reported poverty-level income. Based on the bivariate results, those who reside closer to the coastline or major rivers are more likely to migrate. There is also a positive relationship to migration for those whose household respondent indicated that the household had suffered from cyclone-induced damage over the past decade. Both of these relationships are only significant at the 0.05-level, however. Highly significant are the positive effects on migration of the household location in an area where land use is dominated by shrimp farming and of arable land loss. Salinization issues, however, which are particularly prominent in shrimp-farming areas, have a negligible positive and non-significant association with migration. Arable land loss affected 220 households and was largely attributed to environmental stressors such as riverbank erosion (205 households), polder/embankment failure (9 households), flooding (2 households), and salinity ( 2 households). Land grabbing by musclemen and landlord decisions were less important (8 households). While only 18.5 percent of our households have experienced the hazard of permanently losing arable land, we will see below that it is a potent factor in migration.

Turning to the ownership or control of physical assets, those who hold or cultivate land, i.e., who have access to land regardless of ownership status, and control how much they have or how they use it, are more likely to migrate. Yet, an analysis of the ownership status shows that almost all (93 percent) individuals in our sample who live in households who hold/cultivate land also own land. This suggests migration may be an effect of holding greater assets. Below we evaluate this in relationship to agri-/aquacultural occupations. In terms of housing, those attached to households with higher quality housing are more likely to migrate. Although a higher quality house might suggest greater investment in the local community, it also means greater resources and capacity to move. Access to electricity, on the contrary, which might also be considered an indicator for local investment and stability, seems to have a negative relationship to migration as individuals attached to households with electricity are less likely to migrate. This might reflect proximity to cities and thereby less need to migrate for earnings. 
Table 2. Bivariate relationships between migration (migrant yes/no) and independent variables.

\begin{tabular}{|c|c|c|c|c|}
\hline Indicators/Factors, Total n & Scale & Test & Categories, $\mathrm{n}$ & $\begin{array}{l}\text { Share of Migrants in } \\
\text { Categories or Mean for } \\
\text { Migrants/Non-Migrants }\end{array}$ \\
\hline \multicolumn{5}{|c|}{ General demographics } \\
\hline \multirow{2}{*}{$\begin{array}{l}\text { Gender ** } \\
\mathrm{n}=4456\end{array}$} & \multirow{2}{*}{$\mathrm{D}$} & \multirow{2}{*}{$\mathrm{Chi}^{2}=90.164$} & Male $n=2403$ & 227 migrants $(9.4 \%)$ \\
\hline & & & Female $\mathrm{n}=2053$ & 52 migrants $(2.5 \%)$ \\
\hline \multirow{2}{*}{$\begin{array}{l}\text { Age } \\
\mathrm{n}=4456\end{array}$} & \multirow{2}{*}{ M } & \multirow{2}{*}{ T-Test } & Migrants $n=279$ & Age average $=28$ yrs. \\
\hline & & & Non-migrants $n=4177$ & Age average $=37 \mathrm{yrs}$ \\
\hline \multirow{2}{*}{$\begin{array}{l}\text { Household size } \\
\mathrm{n}=4456\end{array}$} & \multirow{2}{*}{ M } & \multirow{2}{*}{ T-Test } & Migrants $n=279$ & $\varnothing$ no. of $\mathrm{HH}$ members $=5.9$ \\
\hline & & & Non-migrants $n=4177$ & $\varnothing$ no. of $\mathrm{HH}$ members $=5.6$ \\
\hline \multicolumn{5}{|c|}{ Human capital } \\
\hline \multirow{2}{*}{$\begin{array}{l}\text { Education ** } \\
\mathrm{n}=4451\end{array}$} & \multirow{2}{*}{$\mathrm{D}$} & \multirow{2}{*}{$\mathrm{Chi}^{2}=203.53$} & $>=$ Secondary $\mathrm{n}=1095$ & 168 migrants $(15.3 \%)$ \\
\hline & & & $<$ Secondary $\mathrm{n}=3356$ & 111 migrants $(3.3 \%)$ \\
\hline \multirow{2}{*}{$\begin{array}{l}\text { English language proficiency ** } \\
\qquad \mathrm{n}=4456\end{array}$} & \multirow{2}{*}{$\mathrm{D}$} & \multirow{2}{*}{$\mathrm{Chi}^{2}=176.76$} & $>$ Proficiency n = 821 & 151 migrants $(15.5 \%)$ \\
\hline & & & $<$ Proficiency $n=3356$ & 128 migrants $(3.7 \%)$ \\
\hline \multirow{2}{*}{$\begin{array}{l}\text { Student* } \\
\mathrm{n}=4456\end{array}$} & \multirow{2}{*}{$\mathrm{D}$} & \multirow{2}{*}{$\mathrm{Chi}^{2}=5.49$} & Yes $\mathrm{n}=579$ & 49 migrants $(8.5 \%)$ \\
\hline & & & No $n=3877$ & 230 migrants $(5.9 \%)$ \\
\hline \multicolumn{5}{|c|}{ Socio-economic factors/resources } \\
\hline Main occupation in & $\mathrm{D}$ & $\mathrm{Chi}^{2}=4989$ & Yes $n=1271$ & 28 migrants $(2.2 \%)$ \\
\hline $\mathrm{n}=4456$ & & & No $n=3185$ & 251 migrants $(7.9 \%)$ \\
\hline $\begin{array}{l}\text { Main occupation } \\
\text { aculo }\end{array}$ & $\mathrm{D}$ & $\mathrm{Chi}^{2}=297.25$ & Yes $n=925$ & 171 migrants $(18.5 \%)$ \\
\hline $\begin{array}{l}\text { non-agriculture / aquaculture } \\
\qquad \mathrm{n}=4456\end{array}$ & & & No $n=3531$ & 108 migrants $(3.1 \%)$ \\
\hline Non-farm self-employment ${ }^{* *}$ & $D$ & $\mathrm{Ch}^{2}=880$ & Yes $n=693$ & 26 migrants $(3.8 \%)$ \\
\hline $\mathrm{n}=4456$ & & $C 111=0.00$ & No $n=3763$ & 253 migrants $(6.7 \%)$ \\
\hline Average per capita income per month & $D$ & $C h i^{2}=900$ & Below $\mathrm{n}=3790$ & 220 migrants $(5.8 \%)$ \\
\hline$n=4456$ & & & At/above $\mathrm{n}=666$ & 59 migrants $(8.9 \%)$ \\
\hline & & nental hazards a & risks & \\
\hline Shrimp-farming dominated upazila ** & $\mathrm{D}$ & $\mathrm{Chi}^{2}=1072$ & Yes $n=1191$ & 98 migrants $(8.2 \%)$ \\
\hline $\mathrm{n}=4456$ & D & (11 - 10.12 & No $n=3265$ & 181 migrants $(5.5 \%)$ \\
\hline Arable land loss ${ }^{* *}$ & $\mathrm{D}$ & $\mathrm{Chi}^{2}=16.84$ & Yes $n=873$ & 81 migrants $(9.3 \%)$ \\
\hline $\mathrm{n}=4456$ & & & No $\mathrm{n}=3583$ & 198 migrants $(5.5 \%)$ \\
\hline Distance to river/coastline * & M & T-Test & Migrants n = 279 & $\varnothing$ distance $=1095$ meters \\
\hline $\mathrm{n}=4412$ & & & Non-migrants $n=4133$ & $\varnothing$ distance $=1246$ meters \\
\hline Cyclone-induced damage * & $\mathrm{D}$ & $\mathrm{Chi}^{2}=3.99$ & Yes $n=2410$ & 167 migrants $(6.9 \%)$ \\
\hline $\mathrm{n}=4456$ & & & No $n=2046$ & 112 migrants $(5.5 \%)$ \\
\hline Salinization (n.s.) & $\mathrm{D}$ & $\mathrm{Chi}^{2}=2.35$ & Yes $n=1046$ & 76 migrants $(7.3 \%)$ \\
\hline $\mathrm{n}=4456$ & & & No $n=3410$ & 203 migrants $(6.0 \%)$ \\
\hline & & Physical assets & & \\
\hline Land use/cultivation ** & $D$ & $\mathrm{Chi}^{2}-688$ & Yes $n=3279$ & 224 migrants $(6.8 \%)$ \\
\hline $\mathrm{n}=4456$ & & CIII -0.00 & No $\mathrm{n}=1177$ & 55 migrants $(4.7 \%)$ \\
\hline & & & Pacca $n=400$ & 40 migrants $(10 \%)$ \\
\hline $\begin{array}{l}\text { Housing type ** } \\
n=4418\end{array}$ & $\mathrm{~N}$ & $\mathrm{Chi}^{2}=23.94$ & Semi-Pacca n = 1299 & 102 migrants $(7.9 \%)$ \\
\hline & & & Kaccha $n=2719$ & 133 migrants $(4.9 \%)$ \\
\hline Access to electricity ** & D & $\mathrm{Chi}^{2}=10.46$ & Yes $n=1218$ & 54 migrants $(4.4 \%)$ \\
\hline $\mathrm{n}=4390$ & & $811-10.40$ & No $n=3172$ & 225 migrants $(7.1 \%)$ \\
\hline & & Social capital & & \\
\hline Period of residence in community ** & M & T-Test & Migrants $n=279$ & $\varnothing=45.9$ years \\
\hline $\mathrm{n}=4456$ & & & Non-migrants $n=4133$ & $\varnothing=42.9$ years \\
\hline Neighbors help during cyclone ** & $\mathrm{D}$ & $\mathrm{Chi}^{2}=12.41$ & Yes $n=1108$ & 94 migrants $(8.5 \%)$ \\
\hline $\mathrm{n}=4456$ & & & No $n=3348$ & 185 migrants $(5.5 \%)$ \\
\hline Participation in awareness programs ** & $\mathrm{D}$ & $\mathrm{Chi}^{2}=20.863$ & Yes $n=1555$ & 134 migrants $(8.6 \%)$ \\
\hline $\mathrm{n}=4456$ & & & No $n=2901$ & 145 migrants $(5.0 \%)$ \\
\hline $\mathrm{HH}$ offers voluntary community & $\mathrm{D}$ & $\mathrm{Chi}^{2}$ (a) & Yes $n=52$ & 9 migrants $(17.3 \%)$ \\
\hline $\mathrm{n}=4456$ & & & No $n=4404$ & 270 migrants $(6.1 \%)$ \\
\hline
\end{tabular}

${ }^{* *} p<0.01,{ }^{*} p<0.05$, (n.s.) not significant. (a): Test assumptions not met. Scale: $\mathrm{D}=$ Dichotomous; $\mathrm{N}=$ Nominal; $\mathrm{M}=$ Metric. 
Finally, we turn to social capital and community ties, asking first how many years the household head has lived in the village, which shows a moderate positive and significant effect. We further find that individuals living in households whose neighbors have provided important help during or after the most recent storm surge/cyclone-an indicator for social capital-are more likely to migrate. The same applies to households who participate in community awareness-raising programs or volunteer in terms of community service. While test assumptions for the latter IV (volunteering) are not met, all four IVs capture people with stronger ties to the local community which provides them with greater resources to move. This taps a type of horizontal social capital and lies in contrast to the question asked by Mallick and Vogt [35,42] which tapped vertical network ties to elite community elites who control aid and assistance. This indicates the complexity of social capital which includes integration into both horizontal and vertical social networks which may well have opposite effects.

\subsection{Multi-Level Mixed-Effects Regression Models}

While our bivariate data shows some indication of climate-induced migration, this does not seem to be the dominant factor. Other individual and contextual factors, especially resources, seem more important for migration decisions. A multiple regression analysis can shed more light on this issue. As discussed above, a hierarchical multi-leveled model treating individuals nested within households seems the best approach. This is confirmed by the intercorrelation coefficient (ICC, which takes on values between 0 and 1 ) in the empty model, thereby quantifying this aspect [59]. In our data, the ICC measuring individual migration clustering at the household level is 0.39 , indicating that almost 40 percent of the total individual differences in migration are at the household level, while individual characteristics are overall more important. On the union level, the ICC is below 0.09 , suggesting relatively little importance of union variance. We therefore ignore the union level, using a two-level mixed-effects modeling approach with logistic regression. We enter our IVs in hierarchical steps, first beginning with the individual level IVs and then household level IVs. Finally, we show the relative effects of both in a combined model to identify the most important factors behind migration. In some cases, this will show which overlapping factors, like greater income and land tenure, are more important. Table 3 presents the three logistic regression results. We show log odds results to address relative effects: 1.0 constitutes the mean with positive effects above and negative below that ranging to 0 . We used all IVs for which associations with the DV were statistically significant or theoretically important.

Model 1, containing the individual-level controls only, shows that younger household members and particularly males are significantly more likely to migrate. The same is true for those with higher education (secondary school degree or higher, English language proficiency). Finally, while being primarily engaged in paid off-farm work increases the odds of migration, non-agricultural self-employment reduces the odds. Other than English language proficiency, all of these effects will show again in the combined Model 3. Having a poverty-level income does not show significantly, suggesting it is a secondary factor to these other factors. Of these, the largest effects in terms of log odds are being engaged in off-farm work, which increases the odds of migrating by over 9 times, and that for secondary schooling, which increases the odds of migrating by over 3.6 times. These effects are, as in all other multivariate equations, net of all other IVs in the equation.

Model 2 includes only household-level controls. Of the four IVs which are statistically significant, three belong to the group "environmental hazards and risks", where individuals living in households in shrimp-farming areas (2.1) and permanently lost arable land (1.8) -in most cases through erosion-are roughly twice as likely to migrate. A household residence further away from the next large river or the coast decreases the odds of migration, albeit only minimally (0.99). Individuals from households who have strong horizontal social capital (bonding ties) by receiving support from neighbors during or after storms and cyclones are one and a half times as likely to migrate $(z=1.92 ; \log$ odds $=1.5)$. Significantly, several variables that showed earlier in the bivariate analysis-poorer quality housing, electricity access, cyclone-induced costs, access to land, participation 
in climate awareness programs, and offering voluntary support-do not show statistical significance in the regression model, suggesting that if they are causal, their effects are captured by other household-related factors. These effects, which are smaller than in Model 1, are all net of all other IVs in the equation.

Model 3 combines both individual and household level variables, controlling for their respective effects net of other factors. Overall, most of the significant influences on migration found in Models 1 and 2 recur with English language proficiency now non-significant, and distance to river or coast dropping to the 0.10 significance level, but with a very small effect. Being involved in paid off-farm work has the largest effect, increasing the odds by over 10 times, followed by the effects of education (nearly 3 times as likely), living in a shrimp farming area (2.4 times more likely), losing arable land (2.5 times as likely), having access to land (2.2 times as likely) and being networked with helping neighbors (1.6 times as likely). In contrast to Model 2, holding or cultivating land (on household level) now shows to have a strong positive effect on the likelihood of out-migration.

Overall, the general demographic controls show that younger men are more likely to migrate, but the number of household members is not statistically significant. Human capital indicators reveal that holding a secondary or higher schooling degree contributes strongly to the odds of migrating, and that English language proficiency is positive, but no longer significant in the full model. Third, looking at socio-economic and occupational factors, we see that income below the poverty line and primary employment in agri-/aquaculture are not significant. However, being primarily engaged in non-agricultural work strongly increases the odds of migration by over 10 times, making this the strongest factor in the full model. Similarly, being self-employed in non-farm employment-largely small shops, construction and local manufacturing —also boosts the odds of migration.

Looking to environmental stressors, two factors-loss of arable land and living in shrimp-farming areas where there is less labor demand (e.g., [60])—boost out-migration by roughly two and a half times. Living closer to large rivers or the coast increases slightly the odds of migrating, presumably reflecting the hazards of a location close to major water bodies. The other environmental stressor IVs—cyclone damage and salinization-are non-significant, suggesting any impact of these is being picked up by other factors in model 3. Of the physical asset controls, only access to land matters, boosting the odds of migration. This fits the "environmental capital" thesis that access to land often creates resources that can be used to support the migration of family members [2]. Housing quality and access to electricity do not matter in this fuller equation. Finally, those with better horizontal social capital in terms of helpful neighbors in disasters are 1.6 times more likely to move. These horizontal ties serve as a source of information, solidarity and self-help that contributes to out-migration. Other social capital factors, such as duration of residence in the village, voluntary community involvement or participation in local awareness-raising programs are not statistically significant. Overall, Model 3 fits the general finding that those with greater and more flexible resources are more likely to migrate, but there are also significant environmental stressor effects associated with the permanent loss of arable land, living in saltwater shrimp farming areas and proximity to major rivers and the coast.

Table 3. Multi-level mixed-effects logistic regression models of migration decisions.

\begin{tabular}{cccc}
\hline $\begin{array}{c}\text { Dependent Variable: Migration } \\
(\text { Yes }=\mathbf{1}, \mathbf{N o}=\mathbf{0})\end{array}$ & $\begin{array}{c}\text { Model 1 } \\
\text { (Individual Variables) }\end{array}$ & $\begin{array}{c}\text { Model 2 } \\
\text { (Household } \\
\text { Variables) }\end{array}$ & $\begin{array}{c}\text { Model 3 } \\
\text { (Combined) }\end{array}$ \\
\hline General Demographics & & \\
\hline Gender (male = 1, female = 2) & $0.208^{* *}(0.055)$ & - & $0.206^{* *}(0.055)$ \\
\hline Age (years) & $0.942^{* *}(0.009)$ & - & $0.941^{* *}(0.010)$ \\
\hline $\begin{array}{c}\text { Household size (number of persons } \\
\text { in household) }\end{array}$ & - & $1.083(0.057)$ & $1.070(0.087)$ \\
\hline
\end{tabular}


Table 3. Cont.

\begin{tabular}{|c|c|c|c|}
\hline $\begin{array}{l}\text { Dependent Variable: Migration } \\
\qquad(\text { Yes }=1, \text { No }=0)\end{array}$ & $\begin{array}{c}\text { Model } 1 \\
\text { (Individual Variables) }\end{array}$ & $\begin{array}{c}\text { Model } 2 \\
\text { (Household } \\
\text { Variables) }\end{array}$ & $\begin{array}{c}\text { Model } 3 \\
\text { (Combined) }\end{array}$ \\
\hline \multicolumn{4}{|c|}{ Human capital } \\
\hline $\begin{array}{c}\text { Education }(\text { secondary or higher }=1, \\
\text { below }=0 \text { ) }\end{array}$ & $3.609 * *(1.120)$ & - & $2.903^{* *}(0.855)$ \\
\hline $\begin{array}{l}\text { Basic English language proficiency } \\
\text { or higher }(\text { Yes }=1)\end{array}$ & $1.935 *(0.618)$ & - & $1.634(0.512)$ \\
\hline Student $($ Yes = 1) & $0.558(0.227)$ & - & $0.648(0.261)$ \\
\hline \multicolumn{4}{|c|}{ Socio-economic factors/resources } \\
\hline $\begin{array}{c}\text { Main occupation in } \\
\text { agri-/aquaculture }(\text { Yes }=1)\end{array}$ & $0.642(0.267)$ & - & $0.666(0.261)$ \\
\hline $\begin{array}{c}\text { Main occupation in } \\
\text { non-agri-/aquaculture }(\text { Yes }=1)\end{array}$ & $9.435 * *(3.285)$ & - & $10.192 * *(3.548)$ \\
\hline Non-farm self-employment (Yes = 1) & $0.149^{* *}(0.052)$ & - & $0.149 * *(0.052)$ \\
\hline $\begin{array}{c}\text { Income per person below poverty } \\
\text { line }(Y e s=1)\end{array}$ & - & $0.694(0.178)$ & $0.757(0.264)$ \\
\hline \multicolumn{4}{|c|}{ Environmental hazards and risks } \\
\hline $\begin{array}{l}\text { Shrimp farming dominated } \\
\text { area }(\text { Yes }=1)\end{array}$ & - & $2.050 *(0.579)$ & $2.379 *(0.933)$ \\
\hline $\begin{array}{l}\text { Arable land lost (mainly due to } \\
\text { erosion) }(\text { Yes }=1)\end{array}$ & - & $1.819 *(0.416)$ & $2.456^{* *}(0.752)$ \\
\hline Distance to river or coast (meter) & - & $0.9998^{* *}(0.0001)$ & $0.9998\left(^{*}\right)(0.0001)$ \\
\hline Cyclone-induced costs (Yes = 1) & - & $1.114(0.217)$ & $1.014(0.263)$ \\
\hline Salinization (Yes = 1) & - & $0.706(0.181)$ & $0.644(0.239)$ \\
\hline \multicolumn{4}{|c|}{ Physical assets } \\
\hline Land tenancy or cultivation (Yes = 1) & - & $1.276(0.285)$ & $2.202 * *(0.662)$ \\
\hline Housing condition: Pacca $(Y e s=1)$ & - & $1.266(0.424)$ & $1.518(0.659)$ \\
\hline $\begin{array}{l}\text { Housing condition: } \\
\text { Semi-Pacca }(\text { Yes }=1)\end{array}$ & - & $1.143(0.237)$ & $1.087(0.299)$ \\
\hline Access to electricity $(Y e s=1)$ & - & $0.744(0.166)$ & $0.810(0.252)$ \\
\hline \multicolumn{4}{|c|}{ Social capital } \\
\hline Duration of stay in village (years) & - & $1.006(0.005)$ & $1.005(0.007)$ \\
\hline $\begin{array}{l}\text { Neighbors most important help } \\
\text { during last natural disaster (Yes = 1) }\end{array}$ & - & $1.499\left(^{*}\right)(0.308)$ & $1.626\left(^{*}\right)(0.464)$ \\
\hline $\begin{array}{l}\text { Participation in local awareness } \\
\text { programs }(\text { Yes }=1)\end{array}$ & - & $1.258(0.253)$ & $1.010(0.281)$ \\
\hline $\begin{array}{l}\text { Household offers voluntary } \\
\text { community services (Yes = 1) }\end{array}$ & - & $1.839(1.383)$ & $2.349(2.480)$ \\
\hline Constant/Intercept value & $0.259 *(0.165)$ & $0.013^{* *}(0.006)$ & $0.093^{* *}(0.083)$ \\
\hline
\end{tabular}

$\mathrm{n}=4337$, mixed effects multi-level logistic regression, Log pseudolikelihood $=-694.49245$. Cells entries represent the odds ratio, robust standard errors (in parentheses), and level of sig.: $\left.{ }^{* *} p<0.01,{ }^{*} p<0.05,{ }^{*}\right) p<0.1$. Variable Housing condition: Kaccha omitted.

\subsection{Poverty and Stress Interactions}

Past studies have argued that the poor are more exposed to environmental hazards and more likely to migrate. To evaluate this, we added to the IVs in Model 3 a set of interaction terms combining two poverty measures (kaccha housing and below poverty-line income) with our five environmental 
stressors (shrimp farming, loss of arable land, distance from major river/coast, cyclone-induced costs and salinization). Two of these interaction terms were statistically significant and positive, suggesting that the poor are more likely to migrate when residing in kaccha housing and a shrimp-dominated area or experienced significant cyclone damage costs (results not shown but available from the authors). In both of these equations, all other variables remained as significant or non-significant as before, suggesting that these effects are uniquely tied to the conjunction of environmental stress and poverty. Although those with fewer resources may be overall less likely to migrate, there does seem to be some merit to the "last resort" thesis [36] that the poor are distinctively affected in their migration decisions by these two environmental stressors.

\subsection{Temporary vs. permanent and domestic vs. international migration}

In a study of environmental migrants in Bangladesh, Joarder and Miller [61] found that households who had lost assets or become economically insecure due to an environmental hazard were more likely to migrate permanently, while those who lost livestock or crops were more likely to move temporarily. To examine this, we ran mixed-effects regressions of the IVs in Models 1-3 predicting separately temporary and permanent domestic migration (results not shown but available from the authors). Somewhat different from Joarder and Miller [61], the drivers of temporary migrations $(\mathrm{N}=209)$ wer basically the same as all migration except that distance to major rivers or the coast and having helpful neighbors after cyclones were not statistically significant, and salinization was negative and statistically significant. The latter may reflect a hunker-down effect. For permanent domestic migration, females who moved for marriage constituted almost half, which suggests that many of the factors that predicted total migration (off-farm employment, self-employment, loss of arable land, access to land, helpful neighbors) were no longer statistically significant. Loss of arable land, cyclone costs, and living in shrimp farming areas were relevant to both temporary and permanent migration.

We also looked at the drivers of international migration, distinguishing between temporary and permanent international migration. The number of permanent international migrants $(\mathrm{N}=3)$ was too few to create usable results. For temporary international migrants $(\mathrm{N}=31)$, overall results were similar to that for total migration with several differences. Poverty-level income and access to electricity were both negative and statistically significant, and salinization increased the odds of migration. Those from shrimp growing areas were less likely to migrate. The loss of arable land and secondary schooling were not statistically significant. Resources were important, and different environmental stressors (salinization) were important.

Our survey did not ask questions about the destination of out-migrants (other than internal or international), so we cannot distinguish between those who moved to other rural communities vs. regional cities vs. big cities, such as Dhaka. However, of those who provided a main reason for migration, only 2.4 percent moved to improve agricultural employment opportunities and 56.9 percent moved to the city in pursuit of better opportunities. Nor did we collect information on the distance migrated, which is key to assessing gravity theory, but we have been able to show that environmental stress associated with climate change plays a secondary role alongside other resources and opportunities.

\section{Conclusions}

Our main objective was to assess the importance of environmental stress, especially climate-change-related stressors, relative to other drivers of migration. We found that those with greater human capital, access to land, off-farm occupational skills and gender/age roles that promoted a "breadwinner" model were more likely to migrate. Notably, our findings may seem counterintuitive in the sense that we would assume those engaged primarily in agricultural work to be more strongly affected by environmental hazards and hence more likely to move. Rather, our data suggest that those who are not employed in the core agricultural/acquacultural industries of the rural communities are much more likely to migrate, supporting other studies [33] which argue that these people have more 
transferable assets and weaker rural ties which enables them to move more freely. Women's migration, especially for marriage, has a distinct logic that does not respond to most of the factors included in our study and constitutes an important subject for further study. At the same time, we also found that environmental stressors, especially the loss of arable land, distance to a major river or the coast and residing in a shrimp growing area, boosted the odds of migration. Although poverty in terms of housing quality or income was not strongly correlated with any of our environmental stressors, there does seem to be a distinctive effect of poverty-level income with exposure to cyclone damage and residing in a shrimp growing area.

These findings suggest that there are two broad sets of factors shaping migration: resources that facilitate migration, and environmental stressors, especially loss of arable land and, for the poor, cyclone damage and living in a shrimp growing area. Resources are overall the stronger set of factors, but environmental stressors do play a significant, yet secondary role. Most migration is temporary and involves seeking out better opportunities for earnings, school and urban amenities. This suggests that there may be two broad dynamics at work with the more resourceful migrating in response to the perceived gaps between rural and urban areas and another set of less resourceful migrants responding to environmental stressors. At least under current climate conditions, the latter are secondary, but they may well grow in number and importance with future climate changes.

At this point in time, the effects of climate change have been relatively limited, but are anticipated to grow with time. The scenarios painted by some of millions of permanent "climate refugees" are potentially misleading in the stark terms typically portrayed [11-13,55,62], but, if current climate scenarios are correct, in the next 30-50 years sea-level rise and other environmental stressors will present major challenges to coastal resilience. An important step is to study actual migration behavior in the present to see what segments of the rural population are actually migrating, why they go, how long, and where. Studying the sending communities allows one to compare those who migrate vs. those who do not, although this may underestimate the overall extent of migration by missing entire families who have already departed. This is an issue that future work should address.

We further have to recognize that climate change is a broad complex process. Scientifically, it requires 30 to 50 years of weather pattern to infer climate change. Short-term environmental shocks, like riverbank erosion or a storm surge, do not in themselves constitute climate change. As noted at the beginning, coastal Bangladesh shows some signs of climate change in terms of mean annual temperatures, the incidence of extreme flooding, cyclone intensity, and salinization. Further work needs to assess which environmental stressors are actually increasing, their links to climate change and their probable development over the next 30-50+ years. They may well prove as disruptive as some forecasts suggest but likely the main contours of migration will follow the basics of earlier migration that we have been examining.

Author Contributions: Conceptualization, A.B., J.C.J., and B.B.; methodology, A.B., J.C.J., and B.B.; software, A.B.; validation, A.B., J.C.J., and B.B.; formal analysis, A.B.; investigation, A.B.; data curation, A.B.; writing-original draft preparation, A.B., J.C.J., and B.B.; writing-review and editing, A.B., J.C.J., and B.B.; visualization, A.B. and B.B.; supervision, B.B.; project administration, A.B. and B.B.; funding acquisition, J.C.J. and B.B.

Funding: The findings in this paper are based on research that was conducted within the Belmont Forum BanD-AiD project "Collaborative Research-Bangladesh Delta: Assessment of the Causes of Sea-level Rise Hazards and Integrated Development of Predictive Modeling Towards Mitigation and Adaptation". Research was funded by the German Research Foundation (DFG \#BR1678/13-1) and the National Science Foundation (NSF \#1342644).

Acknowledgments: The authors wish to thank Konstantin Gisevius at the University of Cologne and Katka Vrablikova of Ohio State University for their help in processing the data as well as colleagues at Rajshahi University, in particular Raquib Ahmed and Abdullah Al-Maruf, and, at the Institute of Water Modelling, Mohammad Nesaruddin for their priceless support during the fieldwork in coastal Bangladesh.

Conflicts of Interest: The authors declare no conflict of interest. 


\section{Appendix A}

Table A1. Study sites: Selected characteristics and administrative classification [30,63-70].

\begin{tabular}{|c|c|c|c|c|c|c|c|c|c|c|}
\hline District & $\begin{array}{l}\text { Union Parishad } \\
\text { (BBS Code) }\end{array}$ & $\begin{array}{l}\text { Polder } \\
\text { Number }\end{array}$ & $\begin{array}{l}2011 \\
\text { Pop. }\end{array}$ & $\begin{array}{l}\text { Pop. Change } \\
\text { 2001-2011 (\%) }\end{array}$ & $\begin{array}{l}\text { \# HHs } \\
2011\end{array}$ & $\begin{array}{l}\text { Distance to Coast } \\
\text { or Next Major } \\
\text { River (km) }\end{array}$ & $\begin{array}{l}\text { Bio-Ecological } \\
\text { Zone }\end{array}$ & $\begin{array}{c}\text { 2011 Land Use (\%) } \\
\text { (NCA: Net } \\
\text { Cultivated Area) }\end{array}$ & Land Zoning Classification & $\begin{array}{l}\text { Natural Hazards/ } \\
\text { Events }\end{array}$ \\
\hline Khulna & $\begin{array}{l}\text { Amadi } \\
40 / 47 / 53 / 99 / 10\end{array}$ & $10-12$ & 33184 & 18.1 & 7434 & 0.3 & $\begin{array}{l}\text { Saline tidal } \\
\text { floodplain }\end{array}$ & $\begin{array}{c}\text { Agriculture }=61 \\
\text { Settlement }=16 \\
\text { Water body }=21 \\
\text { Galda } / \text { Bagda with } \\
\text { white fish }=15\end{array}$ & $\begin{array}{l}\text { Agro-Aquaculture } \\
\text { (Golda with White Fish) Zone }\end{array}$ & Soil salinity, cyclone-prone \\
\hline Khulna & $\begin{array}{l}\text { Bagali } \\
40 / 47 / 53 / 99 / 11\end{array}$ & $13-14 / 1-2$ & 33027 & 13.9 & 8863 & 1.1 & $\begin{array}{l}\text { Saline tidal } \\
\text { floodplain }\end{array}$ & $\begin{array}{c}\text { Agriculture }=70 \\
\text { Settlement }=14 \\
\text { Water body }=26 \\
\text { Bagda-Galda with } \\
\text { white fish }=32\end{array}$ & $\begin{array}{l}\text { Agro-Aquaculture } \\
\text { (Bagda with white fish) Zone }\end{array}$ & Soil salinity, cyclone-prone \\
\hline Bagerhat & $\begin{array}{c}\text { Rampal } \\
40 / 01 / 73 / 99 / 83\end{array}$ & $34 / 2$ & 24276 & 14.8 & 5840 & 3.5 & $\begin{array}{l}\text { Saline tidal } \\
\text { floodplain }\end{array}$ & $\begin{array}{c}\text { Agricul. }=25 \% \text { of NCA } \\
\text { River } / \text { canal }=11 \\
\text { Shrimp area }=75 \% \text { of NCA } \\
\text { Settlement }=14 \\
\text { Urban }=1\end{array}$ & $\begin{array}{l}\text { Urban and Commercial } \\
\text { and Shrimp (Bagda) Zone }\end{array}$ & $\begin{array}{l}\text { Soil salinity, cyclone-prone Aila: } \\
\text { severe damage } \\
\text { Sidr: moderate damage }\end{array}$ \\
\hline Patuakhali & $\begin{array}{l}\text { Lata Chapli } \\
10 / 78 / 66 / 99 / 47\end{array}$ & 48 & 25925 & 22.2 & 5835 & 1.1 & $\begin{array}{l}\text { Saline tidal } \\
\text { floodplain }\end{array}$ & $\begin{array}{c}\text { Agriculture }=54 \\
\text { Water }=5 \\
\text { Mangrove }=05 \\
\text { Sand }=2 \\
\text { Bay of Bengal }=16 \\
\text { Settlement }=18\end{array}$ & $\begin{array}{c}\text { Agro-Forestry } \\
\text { (Mangrove) and Tourism Zone }\end{array}$ & $\begin{array}{l}\text { Soil salinity, cyclone-prone Sidr: } \\
\text { moderate-severe damage } \\
\text { Mahashen: moderate-severe } \\
\text { damage }\end{array}$ \\
\hline Patuakhali & $\begin{array}{c}\text { Itabaria } \\
10 / 78 / 95 / 99 / 20\end{array}$ & ITL & 21478 & 7.7 & 4490 & 0.5 & $\begin{array}{l}\text { Ganges } \\
\text { floodplain }\end{array}$ & $\begin{array}{l}\text { Agriculture }=50 \\
\text { River } / \text { canal }=17 \\
\text { Tidal flat }=3 \\
\text { Settlement }=30\end{array}$ & $\begin{array}{c}\text { Agro-Fisheries } \\
\text { (open water, river, canal etc.) Zone }\end{array}$ & $\begin{array}{l}\text { Riverbank erosion, cyclone-prone } \\
\text { Sidr: severe damage } \\
\text { Aila: moderate damage }\end{array}$ \\
\hline Patuakhali & $\begin{array}{c}\text { Deuli } \\
\text { Subidkhali } \\
10 / 78 / 76 / 99 / 27\end{array}$ & $47 / 1$ & 32169 & 15.0 & 5033 & 0.4 & $\begin{array}{l}\text { Ganges } \\
\text { Floodplain }\end{array}$ & $\begin{array}{c}\text { Agriculture }=48 \\
\text { Canal } / \text { river }=23 \\
\text { Settlement }=27 \\
\text { Urban }=2\end{array}$ & $\begin{array}{c}\text { Agro- Fisheries } \\
\text { (open water, river, canal) Zone }\end{array}$ & $\begin{array}{l}\text { Riverbank erosion, Cyclone-prone } \\
\text { Sidr: severe damage } \\
\text { Aila: moderate damage }\end{array}$ \\
\hline Lakshmipur & $\begin{array}{l}\text { Char Alexander } \\
20 / 51 / 73 / 99 / 23\end{array}$ & $\begin{array}{c}59 / 2, \\
59 / 2 \mathrm{Ext}\end{array}$ & 40978 & -23.3 & 8447 & 1.2 & $\begin{array}{l}\text { Meghna Estuarine } \\
\text { Floodplain }\end{array}$ & $\begin{array}{c}\text { Agriculture }=32 \\
\text { Settlement with } \\
\text { homestead }=21 \\
\text { Water body }=43 \\
\text { Urban }=2 \\
\text { Tidal Flat }=2\end{array}$ & $\begin{array}{c}\text { Agro-Fisheries } \\
\text { (Open water-river, khal etc.) Zone }\end{array}$ & $\begin{array}{l}\text { Cyclone-prone, severe river bank } \\
\text { erosion }\end{array}$ \\
\hline Noakhali & $\begin{array}{l}\text { Tamaruddin } \\
20 / 75 / 36 / 99 / 95\end{array}$ & 73/1 A-B & 27979 & 10.9 & 6166 & 0.9 & $\begin{array}{l}\text { Offshore } \\
\text { Islands }\end{array}$ & $\begin{array}{c}\text { Agriculture }-43 \\
\text { Mangrove }-07 \\
\text { Settlement }-02 \\
\text { Tidal flat }-12 \\
\text { Water }-37 \\
\end{array}$ & $\begin{array}{l}\text { Agro-Forestry } \\
\text { (Mangrove) Zone }\end{array}$ & $\begin{array}{l}\text { Soil salinity, riverbank erosion, } \\
\text { mildly affected by Sidr/Aila } \\
\text { Severely affected by } 1991 \text { cyclone }\end{array}$ \\
\hline Noakhali & $\begin{array}{l}\text { Char Ishwar } \\
20 / 75 / 36 / 99 / 28\end{array}$ & 73/1 A-B & 26228 & -29.5 & 5381 & 1.5 & $\begin{array}{l}\text { Offshore } \\
\text { Islands }\end{array}$ & $\begin{array}{l}\text { Agriculture }-54 \\
\text { Settlement }-06 \\
\text { Tidal flat }-10 \\
\text { Water }-29 \\
\text { Mangrove }-01\end{array}$ & Agriculture Zone & $\begin{array}{l}\text { Soil salinity, Riverbank erosion but } \\
\text { also char land quickly rising, } \\
\text { mildly affected by Sidr/ /Aila } \\
\text { Severely affected by } 1991 \text { cyclone }\end{array}$ \\
\hline
\end{tabular}




\section{References}

1. Fussell, E.; Hunter, L.M.; Gray, C.L. Measuring the Environmental Dimensions of Human Migration. Glob. Environ. Chang. 2014, 28, 182-191. [CrossRef] [PubMed]

2. Hunter, L.M.; Luna, J.K.; Norton, R.M. Environmental Dimensions of Migration. Annu. Rev. Sociol. 2015, 41,377-397. [CrossRef] [PubMed]

3. Myers, N. Environmental refugees in a globally warmed world. BioScience 1993, 43, 752-761. [CrossRef]

4. Myers, N. Environmental Refugees: A Growing Phenomenon of the 21st Century. Philos. Trans. R. Soc. 2002, B357, 609-613. [CrossRef] [PubMed]

5. International Organization of Migration. Assessing the Evidence: Environment, Climate Change and Migration in Bangladesh; IOM: Geneva, Switzerland, 2010.

6. Nicholls, R.J.; Marinova, N.; Lowe, J.A.; Brown, S.; Vellinga, P.; de Gumão, D.; Hinkel, J.; Tol, R.S.J. Sea-level Rise and its Possible Impacts given a 'Beyond $4{ }^{\circ} \mathrm{C}$ World' in the Twenty-First Century. Philos. Trans. R. Soc. A 2011, 369, 161-181. [CrossRef] [PubMed]

7. Gemenne, F. Why the Numbers Don't Add up: A Review of Estimates and Predictions of People Displaced by Environmental Changes. Glob. Environ. Chang. 2011, 21, S41-S49. [CrossRef]

8. Hartmann, B. Rethinking Climate Refugees and Climate Conflict: Rhetoric, Reality and the Politics of Policy Discourse. J. Int. Dev. 2010, 22, 233-246. [CrossRef]

9. Jakobeit, C.; Methmann, C. "Climate Refugees" as Dawning Catastrophe? A Critique of the Dominant Quest for Numbers. In Climate Change, Human Security and Violent Conflict; Scheffran, J., Brzoska, M., Brauch, H.G., Eds.; Springer: Berlin, Germany, 2012; pp. 301-314.

10. Renaud, F.G.; Dun, O.; Warner, K.; Bogardi, J. A Decision Framework for Environmentally Induced Migration. Int. Migr. 2011, 49, 5-29. [CrossRef]

11. Black, R.; Adger, W.N.; Arnell, N.W.; Dercon, S.; Geddes, A.; Thomas, D. The Effect of Environmental Change on Human Migration. Glob. Environ. Chang. 2011, 21, S3-S11. [CrossRef]

12. Ionesco, D.; Mokhnacheva, D.; Gemenne, F. The Atlas of Environmental Migration; Routledge: London, UK; New York, NY, USA, 2017.

13. Morrissey, J. Rethinking the 'Debate on Environmental Refugees': From 'Maximalists and Minimalists' to 'Proponents and Critics'. J. Political Ecol. 2012, 19, 36-49. [CrossRef]

14. Neumann, K.; Hilderink, H. Opportunities and Challenges for Investigating the Environment-Migration Nexus. Hum. Ecol. 2015, 43, 309-322. [CrossRef] [PubMed]

15. Adams, H. Why Populations Persist: Mobility, Place Attachment and Climate Change. Popul. Environ. 2016, 37, 429-448. [CrossRef]

16. Findlay, A.M. Migrant Destinations in an Era of Environmental Change. Glob. Environ. Chang. 2011, 21, S50-S58. [CrossRef]

17. Brammer, H. Climate Change, Sea-Level Rise and Development in Bangladesh; The University Press: Dhaka, Bangladesh, 2014.

18. Neumann, B.; Vafeidis, A.; Zimmermann, J.; Nicholls, R.J. Future Coastal Population Growth and Exposure to Sea-level Rise and Coastal Flooding-A Global Assessment. PLoS ONE 2015, 10, e0118571. [CrossRef] [PubMed]

19. Paul, B.K.; Rashid, H. Climatic Hazards in Coastal Bangladesh: Non-structural and Structural Solutions; Elsevier: New York, NY, USA, 2017.

20. Rashid, H.; Paul, B. Climate Change in Bangladesh: Confronting Impending Disasters; Lexington Books: New York, NY, USA, 2014.

21. Rahman, R.; Salehin, M. Flood Risks and Reduction Approaches in Bangladesh. In Disaster Risk Reduction Approaches in Bangladesh; Shaw, R., Mallick, F., Islam, A., Eds.; Springer: London, UK, 2013; pp. 65-90.

22. Nicholls, R.J.; Hutton, C.W.; Lázár, A.N.; Allan, A.; Adger, W.N.; Adams, H.; Wolf, J.; Rahman, M.; Salehin, M. Integrated Assessment of Social and Environmental Sustainability Dynamics in the Ganges-Brahmaputra-Meghna Delta, Bangladesh. Estuar. Coast. Shelf Sci. 2016, 183, 370-381. [CrossRef]

23. Hossain, M.S.; Dearing, J.A.; Rahman, M.M.; Salehin, M. Recent Changes in Ecosystem Services and Human Well-Being in the Bangladesh Coastal Zone. Reg. Environ. Chang. 2016, 16, 429-443. [CrossRef]

24. Wilson, C.A.; Goodbred, S.L. Construction and Maintenance of the Ganges-Brahmaputra-Meghna Delta: Linking Process, Morphology and Stratigraphy. Annu. Rev. Mar. Sci. 2015, 7, 67-88. [CrossRef] 
25. Falk, G. Land Use Change in Coastal Regions of Bangladesh. A Critical Discussion of the Impacts on Delta-Morphodynamics, Ecology and Society. ASIEN 2015, 134, 47-71.

26. Auerbach, L.W.; Goodbred, S.L.; Mondal, D.R.; Wilson, C.A.; Ahmed, K.R.; Roy, K.; Steckler, M.S.; Small, C.; Gilligan, J.M.; Ackerly, B.A. Flood Risk of Natural and Embanked Landscapes on the Ganges-Brahmaputra Tidal Delta Plain. Nat. Clim. Chang. Lett. 2015, 5, 153-157. [CrossRef]

27. Swain, A. Displacing the Conflict: Environmental Destruction in Bangladesh and Ethnic Conflict in India. J. Peace Res. 1996, 33, 189-204. [CrossRef]

28. Swapan, M.S.H.; Gavin, M. A desert in the delta: Participatory assessment of changing livelihoods induced by commercial shrimp farming in Southwest Bangladesh. Ocean Coast. Manag. 2011, 54, 45-54. [CrossRef]

29. Ullah, A.K.M.A. Bright City Lights and Slums of Dhaka City: Determinants of Rural-Urban Migration in Bangladesh. Migr. Lett. 2004, 1, 26-41. [CrossRef]

30. BBS Bangladesh Bureau of Statistics. Population Census, 2011. National Series; Union Statistics; BBS: Dhaka, Bangladesh, 2011.

31. Braun, B.; Bernzen, A. Deltas in transition. Climate change, land use and migration in coastal Bangladesh. In Towards Coastal Resilience and Sustainability; Heidkamp, C.P., Morrissey, J., Eds.; Routledge: London, UK; New York, NY, USA, 2019; pp. 188-201.

32. Afsar, R. Internal Migration and the Development Nexus: The Case of Bangladesh. In Regional Conference on Migration, Development \& Pro-Poor Policy Choices in Asia. Dhaka, Bangladesh. 2003. Available online: http:/ / www.research4development.info/PDF/Outputs/MigrationGlobPov/WP-CP2.pdf (accessed on 10 June 2017).

33. Ishtiaque, A.; Ullah, S. The Influence of Factors of Migration on the Migration Status of Rural-Urban Migrants in Dhaka, Bangladesh. Hum. Geogr. 2013, 7, 45-52. [CrossRef]

34. Ahmed, A.U.; Hassan, S.R.; Etzold, B.; Neelorm, S. Where the Rain Falls Project. Case Study: Bangladesh; Report No. 2; United Nations University Institute for Environment and Human Security: Bonn, Germany, 2012.

35. Mallick, B.; Vogt, J. Cyclone, Coastal Society and Migration: Empirical Evidence from Bangladesh. Int. Dev. Plan. Rev. 2012, 34, 217-240. [CrossRef]

36. Penning-Rowsell, E.C.; Sultana, P.; Thompson, P.M. The 'Last Resort'? Population Movement in Response to Climate-related Hazards in Bangladesh. Environ. Sci. Policy 2013, 27, S44-S59. [CrossRef]

37. Hossain, M.Z. Rural-Urban Migration in Bangladesh: A Micro-Level study. In Proceedings of the Brazil IUSSP Conference, Salvador, Brazil, 18-24 August 2001.

38. Hossain, M.Z.; Kazal, M.M.H.; Ahmed, J.U. Rural-Urban Migration and its Implications for Food Security in Bangladesh; National Food Policy Capacity Strengthening Programme: Dhaka, Bangladesh, 2013.

39. Rayhan, M.I. Assessing Household Vulnerability and Coping Strategies to Floods: A Comparative Study of Flooded and Non-flooded Areas in Bangladesh, 2005; Cuvillier Verlag: Göttingen, Germany, 2008.

40. Islam, M.R.; Hasan, M. Climate Induced Human Displacement: A Case Study of Cylone Aila in the South-West Coastal Region of Bangladesh. Nat. Hazards 2016, 81, 1051-1071. [CrossRef]

41. Mallick, B.; Siddiqui, T. Disaster-Induced Migration and Adaptation Discourse in Bangladesh. In Environmental Change, Adaptation and Migration: Bringing in the Region; Hillmann, F., Pahl, M., Rafflenbeul, B., Sterly, H., Eds.; Palgrave: London, UK, 2015; pp. 164-185.

42. Mallick, B.; Vogt, J. Population Displacement after Cyclone and its Consequences: Empirical Evidence from Coastal Bangladesh. Nat. Hazards 2014, 73, 191-212. [CrossRef]

43. Ishtiaque, A.; Nazem, N.I. Household-Level Disaster-Induced Losses and Rural-Urban Migration: Experience from World's One of the Most Disaster-Affected Countries. Nat. Hazards 2017, 86, 315-326. [CrossRef]

44. Islam, T.; Neelim, A. Climate Change in Bangladesh: A Closer Look into Temperature and Rainfall Data; The University Press: Dhaka, Bangladesh, 2010.

45. Banerjee, L. Effects of Flood on Agricultural Productivity in Bangladesh. Oxf. Dev. Stud. 2010, 38, 339-356. [CrossRef]

46. Flood Forecasting and Warning Center and Bangladesh Water Development Board. Annual Flood Report 2014; FFWC/BWDB: Dhaka, Bangladesh, 2014.

47. Singh, O.P.; Khan, T.M.A.; Rahman, S. Has the Frequency of Intense Tropical Cyclones Increased in the North Indian Ocean? Curr. Sci. 2001, 80, 575-580. 
48. Alam, E.; Dominey-Howes, D. A New Catalogue of Tropical Cyclones of the Northern Bay of Bengal and the Distribution and Effects of Selected Landfalling Events in Bangladesh. Int. J. Climatol. 2015, 35, 801-835. [CrossRef]

49. Ahsan, M. Saline Soils of Bangladesh; Soil Resource Development Institute, Ministry of Agriculture: Dhaka, Bangladesh, 2012.

50. Dasgupta, S.; Kamal, F.A.; Khan, Z.H.; Choudhury, S.; Nishat, A. River Salinity and Climate Change: Evidence from Coastal Bangladesh; World Bank: Washington, DC, USA, 2014.

51. Black, R.; Arnell, N.W.; Adger, W.N.; Thomas, D.; Geddes, A. Migration, Immobility and Displacement Outcomes Following Extreme Events. Environ. Sci. Policy 2013, 27, S32-S34. [CrossRef]

52. Azam, M. Factors Driving Environmentally Induced Migration in the Coastal Regions of Bangladesh. Master's Thesis, Albert-Ludwigs-Universität Freiburg, Breisgau, Germany, 6 December 2011.

53. Johnson, F.A.; Hutton, C.W.; Hornby, D.; Lázár, A.; Mukhopadhyay, A. Is Shrimp Farming a Successful Adaptation to Salinity Intrusion? Sustain. Sci. 2016, 11, 423-439. [CrossRef] [PubMed]

54. Azam, M.; Falk, G.C. Governance of Climate Induced Migration in the Coastal Regions of Bangladesh. A New Transformation Required? In Earth System Governance Tokyo Conference Papers. 2013. Available online: https:/ / www.researchgate.net/profile/Mehdi_Azam/publication/270779787_Governance_of_Climate_ Induced_Migration_in_the_Coastal_regions_of_Bangladesh_New_Transformation_Required/links / 54b4cbb70cf26833efd02e24.pdf (accessed on 10 June 2017).

55. Gray, C.L.; Mueller, V. Natural Disasters and Population Mobility in Bangladesh. PNAS 2012, 109, 6000-6005. [CrossRef] [PubMed]

56. Chen, J.J.; Mueller, V.; Jia, Y.; Tseng, S.K.-H. Validating Migration Responses to Flooding Using Satellite and Vital Registration Data. Am. Econ. Rev. 2017, 107, 441-445. [CrossRef]

57. Chen, J.; Mueller, V. Coastal Climate Change, Soil Salinity and Human Migration in Bangladesh. Nat. Clim. Chang. 2018, 8, 981-985. [CrossRef]

58. Akhter, S.; Bauer, S. Household Level Determinants of Rural-Urban Migration in Bangladesh. Int. J. Soc. Behav. Educ. Econ. Bus. Ind. Eng. 2014, 8, 24-27.

59. Merlo, J.; Chaix, B.; Yang, M.; Lynch, J.; Råstam, L. A Brief Conceptual Tutorial of Multilevel Analysis in Social Epidemiology: Linking the Statistical Concept of Clustering to the Idea of Contextual Phenomenon. J. Epidemiol. Community Health 2005, 59, 443-449. [CrossRef]

60. Bernier, Q.; Sultana, P.; Bell, A.R.; Ringler, C. Water Management and Livelihood Choices in Southwestern Bangladesh. J. Rural Stud. 2016, 45, 134-145. [CrossRef]

61. Joarder, M.A.; Miller, P.W. Factors Affecting Whether Environmental Migration is Temporary or Permanent: Evidence from Bangladesh. Glob. Environ. Chang. 2013, 23, 1511-1524. [CrossRef]

62. Call, M.A.; Gray, C.; Yunus, M.; Emch, M. Disruption, not Displacement: Environmental Variability and Temporary Migration in Bangladesh. Glob. Environ. Chang. 2017, 46, 157-165. [CrossRef] [PubMed]

63. BBS Bangladesh Bureau of Statistics. Population Census, 1991: National Series, Union Statistics; BBS: Dhaka, Bangladesh, 1991.

64. Ministry of Land. Land Zoning Report of Ramgati Upazilla of Lakshmipur District; Study of Detailed Coastal Land Zoning; Government of People's Republic of Bangladesh: Dhaka, Bangladesh, 2011.

65. Ministry of Land. Land Zoning Report of Koyra Upazila of Khulna District; Study of Detailed Coastal Land Zoning; Government of People's Republic of Bangladesh: Dhaka, Bangladesh, 2011.

66. Ministry of Land. Land Zoning Report of Rampa Upazila of Bagerhat District; Study of Detailed Coastal Land Zoning; Government of People's Republic of Bangladesh: Dhaka, Bangladesh, 2011.

67. Ministry of Land. Land Zoning Report of Mirzaganj Upazila of Patuakhali District; Study of Detailed Coastal Land Zoning; Government of People's Republic of Bangladesh: Dhaka, Bangladesh, 2011.

68. Ministry of Land. Land Zoning Report of Patuakhali Sadar Upazila of Patuakhali District; Study of Detailed Coastal Land Zoning; Government of People's Republic of Bangladesh: Dhaka, Bangladesh, 2011. 
69. Ministry of Land. Land Zoning Report of Hatiya Upazila of Feni District; Study of Detailed Coastal Land Zoning; Government of People's Republic of Bangladesh: Dhaka, Bangladesh, 2011.

70. Ministry of Land. Land Zoning Report of Kala Para Upazila of Patuakhali District; Study of Detailed Coastal Land Zoning; Government of People's Republic of Bangladesh: Dhaka, Bangladesh, 2011. 